\title{
EKSPLORASI BAKTERI TERMOFILIK DARI SUMBER AIR PANAS AIK SEBAU DI KAWASAN TAMAN NASIONAL GUNUNG RINJANI KABUPATEN LOMBOK TIMUR
}

\section{EXPLORATION OF THERMOPHILIC BACTERIA FROM HOT SPRINGS OF AIK SEBAU IN GUNUNG RINJANI NATIONAL PARK KABUPATEN EAST LOMBOK}

\author{
Syamsul Bahri*1, Fidiani Fidiantara², Yufika Dewi Muksin², Fuad Tamami², A. A. Ayu Trisna \\ Handayani $^{2}$, dan Hermansyah ${ }^{2}$ \\ ${ }^{1}$ Program Studi Pendidikan Biologi, FKIP, Universitas Mataram, Mataram, Indonesia. \\ ${ }^{2}$ Program Studi Magister Pendidikan IPA, Universitas Mataram, Mataram, Indonesia. \\ *Email: syamsulsalihu@yahoo.com
}

Diterima: 18 Januari 2021. Disetujui: 1 Februari 2021. Dipublikasikan: 3 Maret 2021

\begin{abstract}
Abstrak: Sumber air panas adalah mata air yang dihasilkan dari kerak bumi setelah mengalami pemanasan geotermal. Sumber air panas merupakan media pertumbuhan yang cocok bagi bakteri termofilik. Bakteri termofilik merupakan kelompok bakteri yang beradaptasi dengan kondisi lingkungan yang bersuhu tinggi, yaitu dengan suhu berkisar $45^{\circ}-65^{\circ} \mathrm{C}$. Habitat alami bakteri termofilik tersebar luas di seluruh permukaan bumi, diantaranya pada sumber-sumber air panas, kawah gunung berapi atau daerah vulkanik. Tujuan penelitian yaitu mengetahui adanya bakteri termofilik serta melakukan isolasi dan identifikasi karakteristik bakteri termofilik yang berasal dari sumber air panas Aik Sebau, Sembalun Lawang. Metode penelitian ini adalah eksploratif. Penelitian dilakukan dengan 3 tahap, tahap pertama menumbuhkan bakteri pada media yang sesuai, tahap kedua melakukan isolasi dan tahap ketiga melakukan identifikasi untuk mengetahui karakteristik bakteri termofilik meliputi morfologi secara mikroskopi, morfologi koloni dan sifatsifat biokimia. Hasil penelitian diperoleh 7 isolat bakteri termofilik yakni B2a1, B2a2, B2b1, T2a1, T2a2, T2b1, dan A3a1, yang termasuk kedalam genus Bacillus berdasarkan karakteristik fenotipik.
\end{abstract}

Kata kunci: Sumber Air Panas, Bakteri Termofilik

\begin{abstract}
Hot springs are springs produced from the earth's crust after a geothermal heating. Hot springs are a suitable growth medium for thermophilic bacteria. Thermophilic bacteria are a group of bacteria that adapt to the environmental conditions of high temperature, is a temperature range of $45^{\circ}-65^{\circ} \mathrm{C}$. The natural habitat of thermophilic bacteria spread throughout the surface of the earth, including in hot springs, volcanic craters or volcanic areas. The purpose of research is to know the existence of thermophilic bacteria and isolation and identification of the characteristics of thermophilic bacteria from hot springs Aik Sebau, Sembalun Lawang. The method of this research is exploratory. The research was conducted with three stages, the first stage of growing the bacteria on a suitable medium, the second phase of the third stage of isolation and identification to determine the characteristics of thermophilic bacteria include microscopy morphology, colony morphology and biochemical tes. The results were obtained 7 isolates of thermophilic is B2a1, B2a2, B2b1, T2a1, T2a2, T2b1, and A3a1, which belong to the genus Bacillus based on phenotypic characteristics.
\end{abstract}

Keywords: Hot Springs, Thermophilic Bacteria

\section{PENDAHULUAN}

Bakteri ekstremofil merupakan suatu organisme yang mampu bertahan hidup dalam kondisi ekstrem atau bahkan membutuhkan kondisi tersebut untuk beraktivitas dan berkembang biak, sementara bagi makhluk lainnya kondisi tersebut justru mematikan [25]. Salah satu jenis bakteri ekstermofil adalah bakteri termofilik, dimana bakteri termofilik memiliki ketahanan terhadap suhu panas dalam rentang tertentu $[1,16]$. Terdapat tiga faktor yang mampu menyebabkan bakteri termofilik bertahan dan berkembang dalam kondisi suhu yang cukup tinggi, yaitu (1) kandungan enzim dan protein yang lebih stabil serta tahan akan panas dibandingkan dengan bakteri mesofilik, (2) molekul pensistesis protein yang cukup stabil terhadap panas, (3) membrane lipid sel termofilik mengandung banyak asam lemak jenuh yang membentuk ikatan hidrofobik yang cukup kuat [10].

Bakteri termofilik memiliki habitat yang bermacam-macam seperti di letupan hydrothermal, sumber air panas, tumpukan kompos, atau air panas $[12,26]$. Sumber air panas merupakan salah satu objek wisata yang digemari oleh masyarakat, selain untuk menghilangkan stress tempat ini juga dikunjungi dengan beberapa alasan lainnya seperti mengobati insomnia, memperlancar sirkulasi darah dan mengobati jerawat. Di dalam sumber air panas terdapat kandungan berupa mineral sulfat (SO42-), klorida (Cl-), magnesium ( $\mathrm{Mg})$, dan kalsium (Ca) $[17,20]$.

Salah satu sumber mata air panas yang ada Nusa Tenggara Barat (NTB) adalah Sumber Air Panas Air Sebau yang berada di wilayah Desa 
Sembalun Lawang, Kecamatan Sembalun. Menurut penelitian [5, 13] Air Sebau memiliki temperature bawah permukaan sebesar $149^{\circ} \mathrm{C}$ dan temperatur air panas $36.5^{\circ} \mathrm{C}$ dengan temperature udara $19.5^{\circ} \mathrm{C}$ serta pH 8.4. Mata air panas Aik Sebau muncul melalui rekahan pada batuan aliran piroklastik dengan luas manifestasi sekitar $3 \times 4 \mathrm{~m}$, Sembalun, bualan gas dari mata air hangat yang banyak digunakan untuk keperluan pertanian, pemandian dan rumah tangga oleh penduduk sekitar [21].

Penelitian tentang bakteri termofilik sudah banyak dilakukan, seperti yang dilakukan oleh [12] yang berjudul Isolasi Bakteri Termofilik Sumber Air Panas Gedongsongo dengan Media Pengaya MB (Minimal Broth) dan TS (Taoge Sukrosa) serta Identifikasi Fenotip dan Genotip, dengan hasil penelitian bakteri yang didapatkan memiliki kemiripan dengan kelompok Anoxybacillus sp sebesar 94-99\% dan Thermoanaerobacterium sp. sebesar 78-86\%. Begitu juga dengan penelitian yang dilakukan oleh Nadila dengan judul Eksplorasi Bakteri Termofilik Dari Sumber Air Panas Dikawasan Cagar Alam Tinggi Raja Kecamatan Silau Kahen Kabupaten Simalungun Sumatera Utara dengan hasil penelitian menunjukkan bahwa bakteri dari kedua kawah ditemukan dua isolate yang memiliki bentuk koloni bulat bersifat gram positif, motil, dan menghasilkan enzim katalase [4, 10]. Dengan banyaknya penelitian yang ada, tetapi eksplorasi mengenai jenis bakteri termofilik dikawasan sumber air panas Air Sebau belum pernah dilakukan sehingga belum tersedia data mengenai bentuk dan sifat bakteri termofilik dikawasan tersebut, untuk itu perlu dilakukan penelitian untuk mengidentidikasi dan mengenal karateristik bakteri termofilik di sumber air panas Air Sebau, Sembalun Lawang.

\section{METODE PENELITIAN}

\section{Alat dan Bahan}

Alat yang digunakan dalam penelitian adalah Cawan Petri, Tabung reaksi, Jarum Ose, Pipet, Thermometer, Botol Sampel, Tabung Erlenmeyer, Jangka Sorong, Neraca Analitik, Inkubator, Mikroskop, Bunsen, Autoklaf, dan Termos.

Bahan yang digunakan dalam penelitian adalah Alkohol 70\%, Spritus, Aquadest, Alumunium foil, $\mathrm{pH}$ Meter, Kapas, $\mathrm{NaCl} 0.9 \%$, Safranin, Kristal Violet, Iodium, Label, H2O2, Minimal Broth (MB), Simon Citrat Agar (SCA), Triple Sugar Iron Agar (TSIA), Sulft Indol Motility (SIM), Media Uji Glukosa, Laktosa, Maltosa, Pepton, dan Media Uji Hidrolisis Pati.

\section{Prosedur Kerja}

Sampel diambil di sumber ais panas di Kawasan Taman Nasional Gunung Rinjani yakni di
Aik Sebau pada sebanyak $100 \mathrm{ml}$ menggunakan termos. Pengambilan sampel dibagi menjadi 3, yakni pada bagian bawah, tengah, dan atas. Kemudian dilakukan peengecekan suhu dan $\mathrm{pH}$. Sampel air kemudian dibawa ke Laboratorium Biologi FKIP Unram sebelum 24 jam dari waktu pengambilan sampel. Selanjutnya dilakukan inokulasi pada Medium NA dan diinkubasi pada suhu 450C selama 48 jam. Koloni yang tumbuh diisolasi dan dikultur kembali untuk mendapatkan isolate murni. Identifikasi dilakukan dengan mengamati karakter

makroskopis, mikroskopis, dan karakteristik biokimia yang meliputi karakter koloni, sifat gram, uji sitrat, uji motilitas, uji fermentasi gula, uji glukosa, uji laktosa, uji maltosa, uji katalase, dan uji pati.

\section{HASIL DAN PEMBAHASAN}

Penelitian ini menggunakan koloni bakteri termofilik yang di tumbuhkan dari sampel air panas yang diambil dari kawasan sumber air panas Aik Sebau, Sembalun Lawang. Sampel bakteri diambil dari tiga titik bagian sumber air panas, yakni pada bagian Bawah, Tengah dan Atas. Sebelum pengambilan sampel dilakukan pengecekan suhu dan $\mathrm{pH}$, didaptkan hasil suhu dari sumber air panas Aik Sebau adalah $36.5^{\circ} \mathrm{C}$ dengan $\mathrm{pH} 8$.

Masing-masing sampel ditumbuhkan dengan 2 kali ulangan (duplo), sehingga diperoleh kolonikoloni bakteri termofilik yang diamati karakteristiknya. Identifikasi dapat dilakukan secara konvensional melalui karakteristik sifat biokimia dan mikroskopis sel bakteri, hingga berbasis mikroskopis [23]. Hasil pengamatan karakteristik makroskopis diperoleh 7 jenis isolat bakteri yang memiliki karakteristik yang berbeda-beda. Masingmasing jenis isolat diberi kode nama B2a1, B2a2, B2b1, T2a1, T2a2, T2b1, dan A3a1, seperti terlihat pada Tabel 1 .

Hasil pengamatan yang didapatkan berupa bentuk koloni, warna, tepian, dan elevasi. Diperoleh 3 bentuk koloni, yaitu circular, filamentous, dan irregular; karakteristik warna koloni diperoleh 1 warna, yakni hanya putih; karakteristik tepian koloni ada 3 yaitu entire, rhizoid, dan lobate: karakteristik elevasi koloni diperoleh 3 bentuk, yaitu raised, flat, dan crateriform.

Koloni bakteri yang diamati karakteristiknya tersebut diperoleh dari masing-masing sampel air panas yang ditumbuhkan pada media NA dengan metode agar tuang, dimana tiap-tiap titiknya dilakukan 3 kali pengulangan. Koloni bakteri setelah dilakukan pengamatan makroskopis juga dilakukan pengamatan secara mikroskopis berupa sifat Gram positif dan negatif serta bentuk sel bakterinya, seperti terlihat pada Tabel 2. 
Tabel 1. Hasil pengamatan makroskopis karakteristik morfologi koloni bakteri termofilik

\begin{tabular}{ccccccc}
\hline No. & Lapisan & Kode Nama & Bentuk Koloni & Warna & Tepian & Elevasi \\
\hline 1 & Bawah & B2a1 & Circular & Putih & Entire & Raised \\
2 & & B2a2 & Filamentous & Putih & Rhizoid & Flat \\
3 & & B2b1 & Irregular & Putih & Lobate & Raised \\
4 & Tengah & T2a1 & Irregular & Putih & Lobate & Raised \\
5 & & T2a2 & Circular & Putih & Lobate & Crateriform \\
6 & & T2b1 & Circular & Putih & Entire & Flat \\
7 & Atas & A3a1 & Circular & Putih & Entire & Raised \\
\hline
\end{tabular}

Keterangan Tabel 1:

B2a1: Lapisan Bawah, kelarutan ke 2, sampel pertama, koloni bakteri 1. B2a2: Lapisan Bawah, kelarutan ke 2, sampel pertama, koloni bakteri 2. B2b1: Lapisan Bawah, kelarutan ke 2, sampel kedua, koloni bakteri 1. T2a1: Lapisan Tengah, kelarutan ke 2, sampel pertama, koloni bakteri 1. T2a2: Lapisan Tengah, kelarutan ke 2, sampel pertama, koloni bakteri 2. T2b1: Lapisan Tengah, kelarutan ke 2, sampel kedua, koloni bakteri 1. A3a1: Lapisan Atas, kelarutan ke 3, sampel pertama, koloni bakteri 1 .

Tabel 2. Hasil Pengamatan Mikroskopis Bakteri Termofilik

\begin{tabular}{ccccc}
\hline No. & Lapisan & Kode Nama & Bentuk Sel & Sifat Gram \\
\hline 1 & Bawah & B2a1 & Batang & Negatif \\
2 & & B2a2 & Batang & Negatif \\
3 & & B2b1 & Filamentous & Negatif \\
4 & Tengah & T2a1 & Batang & Negatif \\
5 & & T2a2 & Batang & Negatif \\
6 & & T2b1 & Batang & Negatif \\
7 & Atas & A3a1 & Batang & Negatif \\
\hline
\end{tabular}

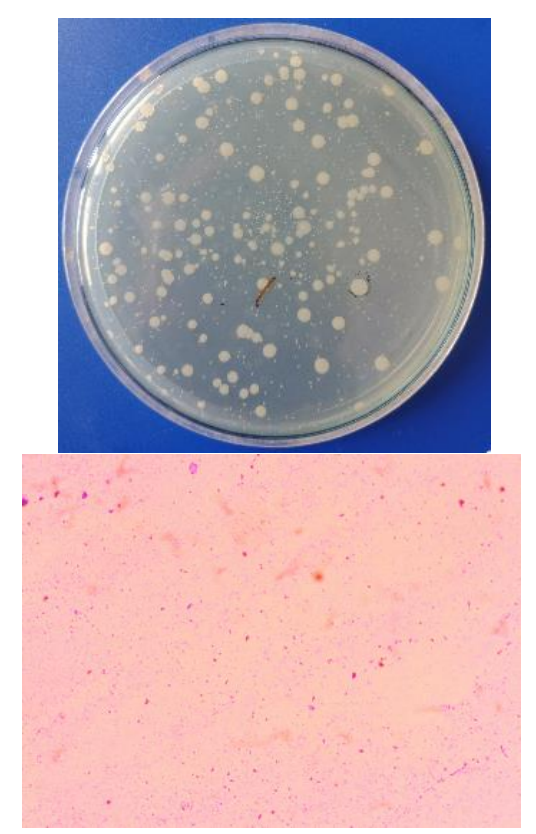

a. B2a1 (Monobacillus)

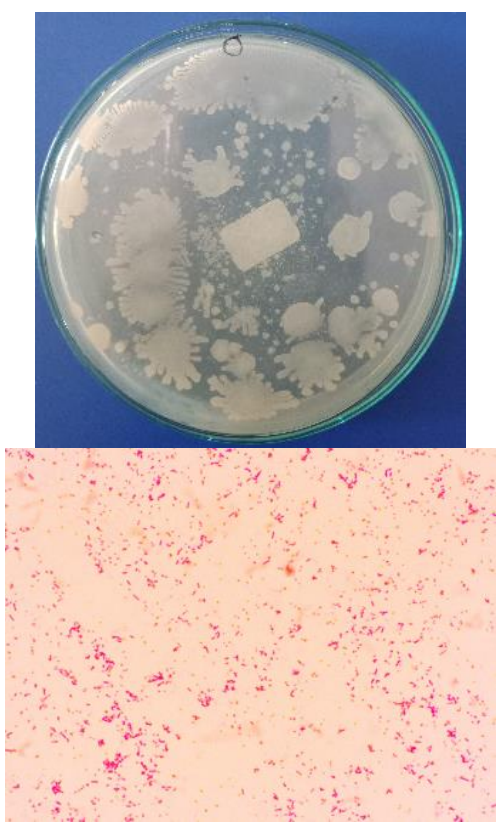

b. T2a1 (Diplobacillus)
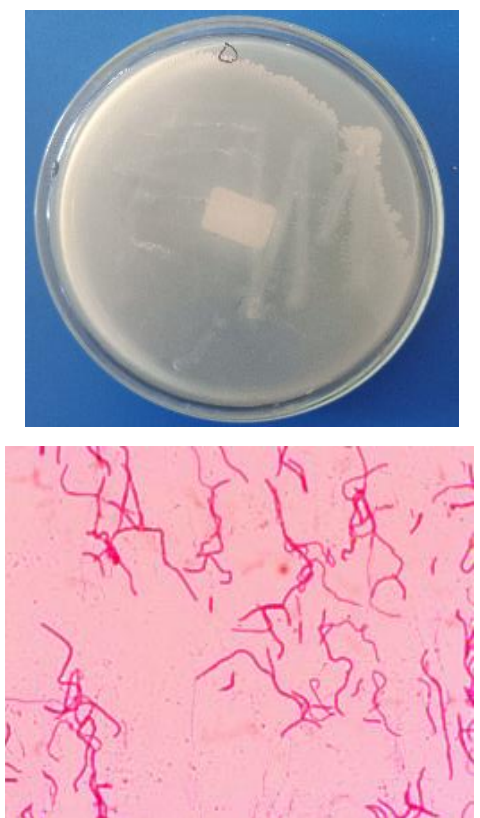

c. B2b1 (Streptobacillus)

Gambar 1 Pengamatan Mikroskopis Koloni Bakteri pada Lapisan Bawah

Hasil pewarnaan Gram dari masing-masing isolat didapatkan hasil bahwa semua koloni bakteri yang didapatkan bersifat Gram negatif dengan bentuk sel Batang. Untuk bentuk sel sendiri meskipun sama-sama berbentuk batang namun memiliki bentuk sel batang yang berbeda, pada koloni bakteri B2b1 memiliki bentuk batang streptobacillus, dan untuk koloni bakteri yang lain memiliki bentuk monobacillus dan diplobacillus, seperti terlihat pada Gambar 1.

Setelah dilakukan pengamatan secara makroskopis dan mikroskopis, dilakukan uji 
biokimia pada masing-masing koloni bakteri. Adapun uji biokimia yang dilakukan yakni, Uji Biokimia yakni Uji Sitrat, Uji Motilitas, Uji Fermentasi Gula, Uji Katalase, Uji Glukosa, Uji Laktosa, Uji Maltosa, dan Uji Pati. Adapun hasi Uji Biokimia bisa dilihat pada table 3 .

Dari hasil uji biokimia didapatkan hasil yang bervariasi, dimana untuk uji glukosa dan uji pati didapatkan hasil positif, yang berarti bakteri termofilik mampu untuk memfermentasi gula dan menghidrolisis pati. Sedangkan untuk uji fermentasi gula didapatkan hasil negetif untuk semua bakteri termofilik, dan untuk uji biokimia lainya hasilnya bervariasi.

Bakteri termofilik ditumbuhkan dari air panas Aik Sebau yang terdapat di kawasan Taman Nasional Gunung Rinjani. Sampel bakteri diambil dari tiga titik pengamatan, yakni lapisan bawah, tengah dan atas. Sumber air panas Aik Sebau memiliki suhu sebesar $36.5^{\circ} \mathrm{C}$ dengan $\mathrm{pH}$ 8. Hal ini sesuai dengan yang didapatkan [5] bahwa Manifestasi panas bumi berupa mata air panas Sebau dengan suhu $36.5^{\circ} \mathrm{C}$, T udara $19.5^{\circ} \mathrm{C}$, pH 8.4 dan daya hantar listrik yang sekitar $1802 \mu \mathrm{S} / \mathrm{cm}$ debit air sekitar 2 liter/detik.

Sampel air dari titik pengamatan akan ditumbuhkan dengan suhu inkubasi $45^{\circ} \mathrm{C}$. Suhu inkubasi $45^{\circ} \mathrm{C}$ ini merupakan kisaran suhu optimum bagi pertumbuhan bakteri termofilik yang artinya pada suhu tersebut bakteri dapat tumbuh dengan baik. Hal ini sesuai dengan pernyataan [7, 14, 19] suhu optimum bagi bakteri termofilik yaitu kisaran $45^{\circ} \mathrm{C}-65^{\circ} \mathrm{C}$.

Berdasarkan hasil penelitian, setelah dilakukan proses penumbuhan bakteri dan proses isolasi diperoleh 7 jenis isolat bakteri termofilik yang terdapat sumber air panas Aik Sebau. Masingmasing isolat tersebut diberi kode nama untuk membedakannya, yakni B2a1, B2a2, B2b1, T2a1, T2a2, T2b1, dan A3a1. Pemberian kode nama yang berbeda ini menunjukkan bahwa setiap isolat tersebut memiliki karakteristik yang berbeda-beda. Bakteri termofilik memiliki karakteristik yang berbeda-beda baik secara makroskopis maupun mikroskopis. Hasil pengamatan makroskopis menunjukkan karakteristik yang bervariasi baik dari segi bentuk koloni, tepi koloni, elevasi koloni, warna koloni, permukaan koloni serta lendir yang dihasilkan.

Hasil penelitian [11], yang berhasil mengisolasi 4 bakteri termofilik yang bersumber dari air panas Songgoriti dengan suhu $45^{\circ} \mathrm{C}$. Karakteristik morfologi koloni bakteri pada suatu media yaitu bentuk koloni berupa bulat, berbenang, tak teratur, serupa akar, dan serupa kumparan. Elevasi koloni berupa datar, timbul datar, melengkung dan membukit. Tepi koloni dapat berupa licin, berombak, berbelah, bergerigi berbenang dan keriting. Warna koloni berupa keputih-putihan, kekuning-kuningan, kelabu atau hampir bening.

Hasil penelitian lain yaitu menurut [15] dari sumber air panas sungai Medang, hasil penelitiannya menunjukkan bentuk koloni yaitu bundar dan tak beraturan; tepian koloni yaitu berombak dan licin; elevasi koloni yaitu timbul dan datar; Warna koloni yaitu krem dan kuning; serta permukaan koloni ada yang halus dan kasar. Dimana hasil penelitiannya hampir sama dengan karakteristik bakteri termofilik yang terdapat di sumber air panas Aik Sebau, Sembalun.

Karakteristik lain yang dilihat dari bakteri termofilik yaitu pengamatan mikroskopis baik sifat Gram maupun bentuk selnya. Berdasarkan hasil pengamatan diperoleh, dan menunjukkan bentuk sel batang (bacill) dan berwarna merah yang merupakan bakteri bersifat Gram negatif. Namun isolat menunjukkan bentuk sel spiral tetapi juga bersifat Gram negatif (Tabel 4.2).

Tabel 3. Hasil Uji Biokimia

\begin{tabular}{ccccccccccc}
\hline No. & Lapisan & Kode Nama & U. S & U. M & U. FG & U. G & U. L & U. M & U. K & U. P \\
\hline 1 & Bawah & B2a1 & - & + & - & + & + & + & - & + \\
2 & & B2a2 & - & + & - & + & - & - & - & + \\
3 & & B2b1 & + & + & - & + & - & - & + & + \\
4 & Tengah & T2a1 & - & + & - & + & - & - & + & + \\
5 & & T2a2 & - & + & - & + & - & - & + & + \\
6 & & T2b1 & - & + & - & + & - & - & + & + \\
7 & Atas & A3a1 & - & - & - & + & + & + & + & + \\
\hline
\end{tabular}

Keterangan:

-: negative, +: positif, U. S: Uji Sitrat, U. M: Uji Motilitas, U. FG: Uji Fermentasi Gula, U. G: Uji Glukosa,

U. L: Uji Laktase, U. M: Uji Maltase, U. K: Uji Katalase, U. P: Uji Pati. 
Bakteri Gram positif hanya mempunyai membran plasma tunggal yang dikelilingi dinding sel tebal berupa peptidoglikan. Sekitar $90 \%$ dari dinding sel tersebut tersusun atas peptidoglikan sedangkan sisanya berupa molekul lain bernama asam teikhoat. Bakteri Gram positif memiliki kandungan lipid rendah dibandingkan dengan bakteri gram negative Sel bakteri negatif mempunyai dinding komplek yang mengandung membran luar dan membran tengah. Membran luar tersusun oleh lipoposakarida (LPS), lipoprotein (LP), dan fosfolipit.

Bakteri gram negatif menghasilkan warna merah dengan tebal peptidoglikan bakteri gram negatif hanya sebesar 2-7 nm dan memiliki membran luar dengan tebal $7-8 \mathrm{~nm}$ yang terdiri dari lipid, protein dan lipopolisakarida yang berakibat pada banyaknya kristal violet yang diserap oleh bakteri gram negatif lebih kecil $[11,14]$.

Bakteri termofilik merupakan bakteri yang hidup pada kondisi ekstrim. Bakteri yang hidup pada kondisi ekstrim memiliki kemampuan khusus dalam mempertahankan hidupnya. Dalam penelitian dilakukan 8 Uji Biokimia yakni Uji Sitrat, Uji Motilitas, Uji Fermentasi Gula, Uji Katalase, Uji Glukosa, Uji Laktosa, Uji Maltosa, dan Uji Pati. Dari hasil uji biokimia didapatkan hasil yang bervariasi. Uji sitrat dilakukan dengan menginokulasi isolat pada media Simmon's Citrate (SC). Pengujian ini bertujuan untuk melihat kemampuan bakteri dalam menggunakan sitrat sebagai satu-satunya sumber karbon dan energy [2]. Hasil positif akan ditunjukkan dengan adanya perubahan warna media dari hijau menjadi biru. Hanya satu koloni bakteri yang menunjukkan hasil positif yakni B2b1.

Uji motilitas digunakan untuk melihat pergerakan bakteri. Dilakukan dengan cara satu ose jarum bakteri ditanam secara tegak lurus di tengah Medium SIM (Sulfit Indol Motility) dengan cara ditusukkan, diinkubasi pada suhu $45^{\circ} \mathrm{C}$ selama 48 jam.Terdapat 6 koloni bakteri yang menunjukkan hasil positif yakni B2a1, B2a2, B2b1, T2a1, T2a2, dan T2b1. Bakteri termofilik memiliki sifat motil (bergerak) dan mobilitasnya disebabkan oleh flagel [24].

Uji Fermentasi Gula menggunakan media TSIA bertujuan untuk mengetahui kemampuan bakteri dalam memfermentasi glukosa, laktosa, sukrosa, pembentukan $\mathrm{H} 2 \mathrm{~S}$ dan gas. Hasil positif akan ditunjukkan dengan adanya perubahan warna media dari coklat menjadi merah apabila mengandung glukosa dan berwarna kuning apabila mengandung sukrosa dan maltose [3]. Hasil penelitian menunjukkan bahwa semua koloni yang didapatkan tidak mengalami perubahan warna yang berarti bahwa semua koloni bakteri tidak dapat memfermentasikan gula.
Uji Glukosa bertujuan untuk mengetahui apakah bakteri memfermentasi glukosa dan membentuk asam dan gas, dari hasil penelitian semua koloni dapat memfermentasi glukosa membentuk asam dan gas [6]. Uji Laktosa bertujuan untuk mengetahui apakah bakteri memfermentasi laktosa dan membentuk asam dan gas, dari hasil penelitian koloni bakteri yang dapat memfermentasi laktosa membentuk asam dan gas adalah B2a1 dan A3a1. Dan Uji Maltosa bertujuan untuk mengetahui apakah bakteri memfermentasi maltosa dan membentuk asam dan gas, dari hasil penelitian koloni bakteri yang dapat memfermentasi laktosa membentuk asam dan gas adalah sama dengan koloni bakteri yang dapat mempfermentasi loktosa yakni B2a1 dan A3a1.

Uji katalase digunakan untuk mengetahui aktivitas katalase pada bakteri yang diuji. Kebanyakan bakteri memproduksi enzim katalase yang dapat memecah $\mathrm{H}_{2} \mathrm{O}_{2}$ menjadi $\mathrm{H}_{2} \mathrm{O}$ dan $\mathrm{O}_{2}$ [8, 9, 18]. Uji ini dengan langkah mengambil: 1 mata ose koloni dari media BAP letakan pada objek glass yang steril, ratakan koloni jangan sampai menumpuk, kemudian ditetesi dengan 1-2 tetes $\mathrm{H}_{2} \mathrm{O}_{2} 3 \%$, amati ada atau tidaknya gelembung jika ada gelembung maka uji katalase positif sebaliknya jika tidak ada gelembung maka uji katalase negative. Hasil dari peneltian menunjukkan bahwa koloni bakteri yang memproduksi enzim katalase ada 5 yakni B2b1, T2a1, T2a2, T2b1, dan A3a1.

Uji pati bertujuan untuk mengetahui apakah bakteri memiliki aktivitas amilolitik atau dapat menghidrolisis pati. Dari hasil pengamatan didapatkan bahwa semua koloni bakteri yang ada dapat menghidrolisi pati.

Berdasarkan peneltian yang dilakukan oleh [12] didapatkan bahwa Isolat yang ditemukan yakni GS_MBan memiliki kemiripan dengan bakteri kelompok Anoxybacillus sp. sebesar 94-99\%; merupakan bakteri anaerob, berbentuk batang, gram positif, memiliki enzim ekstraseluler a-amilase, protease dan P-galaktosidase. Isolat GS_TSan memiliki kemiripan dengan bakteri kelompok Thermoanaerobacterium sp. Sebesar 78-86\%; merupakan bakteri anaerob, berbentuk batang, gram negatif, memiliki enzim ekstraseluler $\alpha$-amilase dan protease. Dimana berdasarkan hasil yang didapatkan dari sumber air panas Aik Sebau, bentuk koloni mirip dengan Sampel bakteri B2a1 dan B2a2.

Pada penelitian Identifikasi bakteri termofilik yang dilakukan oleh [18] didapatkan 7 koloni bakteri yang kemudian dilihat karakteristik makroskopis, mikroskopis dan sifat biokimia sesuai penjelasan berdasarkan Bergey Manual of Systematic Bacteriology Second Edition Volume Four dimana dapat disimpulkan bahwa semua isolate (7 isolat) masuk kedalam genus Bacillus. Dimana hasil yang didapatkan memiliki kemiripan dengan koloni bakteri B2b1 yang memiliki 
kemampuan dalam menggunakan sitrat sebagai satu-satunya sumber karbon dan energy dan bersifat motil [24].

Beberapa spesies Bacillus yang merupakan bakteri termofilik seperti, Bacillus coagulans, Bacillus fumarioli, Bacillus infernus, Bacillus methanolicus, Bacillus okuhidensis, Bacillus smithii, Bacillus thermoamylovorans dan Bacillus tusciae, memiliki suhu pertumbuhan mulai dari $40^{\circ} \mathrm{C}$ hingga $55^{\circ}$ [22]. Dimana berdasarkan hasil penelitian yang dilakukan oleh Tuntun menemukan 7 koloni bakteri yang memiliki ciri-ciri secara makroskopis seperti T2a1, T2a2, T2b1, dan A3a1. Dari hasil penelitian didapatkan hasil Uji Biokimia yang beragam.

\section{KESIMPULAN}

Pada penelitian ini Identifikasi dilakukan berdasarkan karakter fenotipik dengan melihat karakteristik makroskopis, mikroskopis dan sifat biokimia sesuai penjelasan dari beberapa artikel penelitian sebelumnya, sehingga dapat disimpulkan bahwa semua isolate (7 isolat) masuk kedalam genus Bacillus.Untuk penelitian lanjutan diperlukan identifikasi hingga tingkat jenis dari berbagai isolat yang diperoleh. Disarankan bahwa perlu tindaklanjut karakterisasi uji seperti sifat pertumbuhan dalam berbagai media dan karakter biokimia lainnya yang belum tercakup dalam penelitian ini sehingga dapat dilakukan identifikasi secara taksonomi numerik. Metode lainnya adalah identifikasi secara molekuler berdasarkan gen $16 \mathrm{~S}$ rRNA.

\section{DAFTAR PUSTAKA}

[1] Agustien, A. (2010). Protease Bakteri Termofilik.Bandung: UNPAD PRESS.

[2] Dani, I. (2015). Ciri-Ciri Klasifikasi dan Peranan.https://pak.pandani.web.id/2015/09/cir i-ciri-klasifikasi-dan-peranan.html. (21 Agustus 2020).

[3] Dessy, Y. (2008). Isolation \& Identification of Thermophilic Microorganism from Wayang Crater. Jakarta: Mikrobiol.

[4] Edwards, C. (1990). Thermophiles In: Edwards C (ed) Microbiology of extreme environments. Oxford: Open University.

[5] Hadi, M. N., Yushantarti, A., Suhanto, E., \& Sundhoro, H. (2007). Survei panas bumi terpadu (geologi, geokimia dan geofisika) daerah Sembalun, Kabupaten Lombok TimurNTB. In Prociding.

[6] Hartiko, K.A. (1992). Rancangan Percobaan: Teori dan Aplikasi, F.P. Universitas Sriwijaya Palembang. Jakarta: PT Raja Grafindo Persada.

[7] Kurniawati, D. (2012). Skripsi. Seleksi, Karakterisasi, Dan Identifikasi Isolat Bakteri Termofilik Pasca Erupsi Merapi Sebagai
Penghasil Enzim Protease. Yogyakarta: Universitas Negri Yogyakarta.

[8] Madigan, M. T., Martinko, J. M., \& Parker, J. (2009). Brock's Biology of Microorganisms 9th Ed. Prentice Hall Internasional, Inc. New Jersey.

[9] Muharni. (2010). Isolasi dan Identifikasi Bakteri Penghasil Kitinase dari Sumber Air Panas Danau Ranau Sumatera Selatan. Jurnal Penelian Sains, 0(1), 6-9.

[10] Nadila, P. (2019). Dissertstion. Eksplorasi Bakteri Termofilik dari Sumber Air Panas Dikawasan Cagar Alam Tinggi Raja Kecamatan Silau Kahen Kabupaten Simalungun Sumatera Utara. Medan: Universitas Medan Area.

[11] Nuniek H, (2009). Kitinase dan mikroorganisme kitinolitik. Jurnal Chem, 1(9), $1-5$.

[12] Nuritasari, D., Sarjono, P. R., \& Aminin, A. L. (2017). Isolasi Bakteri Termofilik Sumber Air Panas Gedongsongo dengan Media Pengaya MB (Minimal Broth) dan TS (Taoge Sukrosa) serta Identifikasi Fenotip dan Genotip. Jurnal Kimia Sains dan Aplikasi, 20(2), 84-91.

[13] Prana, A. W. (2018). Policy Directions of Geothermal Potential at Sembalun District of East Lombok Regency in Nusa Tenggara Barat Province, Indonesia. Sumatra Journal of Disaster, Geography and Geography Education. 2(1), 71-76.

[14] Prescott. (2008). Microbiology 7th edition. USA: McGraw-Hill Book Company.

[15] Rahmadani, A, dkk., (2015). Isolasi dan Karakteristik Bakteri Amilotermofilik Dari Sumber Air Panas Sungai Medang. Jurnal Biologi Universitas Andalan, 2(4).

[16] Respati, N. Y., Yulianti, E., \& Rahmawati, A. (2017). Optimasi Suhu Dan pH Media Pertumbuhan Bakteri Pelarut Fosfat Dari Isolat Bakteri Termofilik. Biologi-S1. 6(7), 423-430.

[17] Rizkiyah, I. (2013). Dissertstion. Identifikasi kandungan mineral sulfat (SO42-), Klorida (Cl), magnesium ( $\mathrm{Mg}$ ), dan kalsium (Ca) dalam air panas pada obyek wisata pemandian air panas Guci Tegal. Tegal: IAIN Walisongo.

[18] Roslina, U. (2009). Skrining Bakteri Termofilik Penghasil Protease. Buletin Teknisi Litkayasa Akuakultur. 6(2), 146-155.

[19] Sanifitri, E.H. (2007). Skripsi. Aplifikasi gen 16SrRNA Bakteri Termofilik Dari Sumber Air Panas, Gunung Pancar Bogor. Bogor: FMIPA IPB.

[20] Scandurra H, (1998). Energi Geothermal. Pertamina. Jakarta: Airlangga.

[21] Soetoyo, S. (2008). Vulcano Tektonic Deprestion Di Lapangan Panas Bumi Sembalun, Lombok Timur, Nusa Tenggara Barat. Buletin Sumber Daya Geologi. 3(3), 4657. 
[22] Tarigan, P. (1988). Proteinase. Microbial Enzyme and Biotechnology. Jakarta: Applied Science Publisher.

[23] Utari, Indah Budi. (2011). Skripsi. Identifikasi Bakteri Termofilik Amilolitik Dari Mata Air Panas Cienang Dan Gunung Darajat, Garut. Bandung: UPI.

[24] Volk dan Wheeler. (1988). Mikrobiologi Dasar, Edisi 5 Jilid 1. Jakarta: Airlangga.

[25]Zilda, D. S. (2008). Ekstremofil Sebagai Penghasil Enzim Yang Potensial Untuk Aplikasi Industri Pangan Dan Non Pangan. Penelitian Pada Balai Besar Riset Pengolahan Produk dan Bioteknologi Kelautan dan Perikanan, 3(1), 51-57.

[26] Zubaidah, S. 2000. Mikrobiologi Air. Jakarta: Airlangga. 